\title{
SYNTHESIS, ANTIMICROBIAL EVALUATION AND IN SILICO STUDIES OF THE (E)-3-(ARYL)-5-STYRYL-1,2,4-OXADIAZOLES
}

\author{
Josefa Aqueline da Cunha LIMA ${ }^{1}$ (i), Erick Caique Santos COSTA ${ }^{2}$ (D), Giselle Barbosa BEZERRA ${ }^{3}$ (D), \\ Jadson de Farias SILVA ${ }^{3}$ (D), Rodrigo Ribeiro Alves CAIANA ${ }^{2}$ iD, Joao Rufino de FREITAS FILHO ${ }^{1}$ (D), \\ Juliano Carlo Rufino FREITAS 4 iD
}

\footnotetext{
${ }^{1}$ Postgraduate Program in Chemistry, Rural Federal University of Pernambuco, Recife, Pernambuco, Brazil.

2 Postgraduate Program in Natural Sciences and Biotechnology, Federal University of Campina Grande, Cuité, Paraíba, Brazil.

${ }^{3}$ Postgraduate Program in Chemistry, Rural Federal University of Pernambuco, Recife, Pernambuco, Brazil.

${ }^{4}$ Education and Health Center, Federal University of Campina Grande, Cuité, Paraíba, Brazil.
}

Corresponding author:

Juliano Carlo Rufino Freitas

Email: julianocrufino@pq.cnpq.br

How to cite: LIMA, J.A.C., et al. Synthesis, antimicrobial evaluation and in silico studies of the (e)-3-(aryl)-5-styryl-1,2,4-oxadiazoles. Bioscience Journal. 2022, 38, e38005. https://doi.org/10.14393/BJ-v38n0a2022-54382

\begin{abstract}
In recent years, investigations in the field of oxadiazoles have been intensified due to their numerous therapeutic uses. Oxadiazoles are a class of compounds that exhibit several biological applications, citing antimicrobial, anti-inflammatory, anti-diabetic, anthelmintic, anti-tumor, among others. Encouraged by the biological potential of oxadiazoles, were carried out synthesis, antimicrobial evaluation and in silica studies of five (E)-3-(aryl)-5-styryl-1,2,4-oxadiazoles. In this way, (Z)-aryl- $N$ '-hydroxybenzimidamides and ethyl $(E)$ cinnamate were synthesized, which were subjected to an $O$-acylamidoxime reaction after by dehydration using microwave irradiation to form the oxadiazole nucleus. The compounds were characterized by spectroscopic techniques, while in vitro antimicrobial activity was evaluated against S. aureus, E. faecalis, $E$. coli, $P$. aeruginosa, and against the fungus $C$. utilis using the microplate microdilution method. Thus, (Z)-aryl$N^{\prime}$-hydroxybenzimidamides, ethyl (E)-cinnamate, and (E)-3-(aryl)-5-styryl-1,2,4-oxadiazoles were synthesized with yields ranging from moderate to good. The (E)-3-(aryl)-5-styryl-1,2,4-oxadiazoles exhibited a reduced spectrum of action, which were active against the bacterium $P$. aeruginosa and for the fungus $C$. utilis.
\end{abstract}

Keywords: Antimicrobial activity. In silico. Oxadiazole. Synthesis.

\section{Introduction}

Currently, the search for new antimicrobials is necessary and urgent, since infectious diseases are the second leading cause of death worldwide (Guimarães et al. 2010; Duval et al. 2019). In addition, the increase in hospital infections caused by pathogens multi-resistant to commercial drugs is another factor that intensifies the need for new antimicrobials with other modes of action (Guimarães et al. 2010; Terrível et al. 2013). According to data from the World Health Organization (WHO), there is a spontaneous tendency for conventional antibiotics to lose their clinical efficacy due precisely to the increase in microbial resistance, which will hinder the treatment of patients affected by infectious diseases (Terrivel et al. 2013).

In general, antibiotics can be defined as compounds of natural or synthetic origin capable of killing fungi or bacteria (bactericidal) or preventing their growth (bacteriostatic) (Walsh 2004). It is worth mentioning that antibiotics of natural or semi-synthetic origin can be classified as $\beta$-lactams, to mention 
penicillins, cephalosporins, carbapenems, oxapenems, and monobactams; tetracyclines, which are aminoglycosides, macrolides, cyclic peptides (glycopeptides, lipodepsipeptides); streptogramins; in addition to lincosamides, chloramphenicol, rifamycins, among others (Guimarães et al. 2010). Antibiotics of synthetic origin can be classified as sulfonamides, fluoroquinolones, and oxazolidinones (Rossiter et al. 2017).

Given this scenario, the 3,5-disubstituted 1,2,4-oxadiazoles have been highlighted due to their scientific relevance, mainly in the biological and pharmacological areas, since they exhibit action antimicrobial, anti-inflammatory, anti-diabetic, anthelmintic, anti-tumor, among others (Cunha and Aguiar 2015). These compounds participate directly in the drug-receptor interaction, being able to act as a pharmacophoric group or contributing, due to their rigidity, to the proper positioning of the substituents linked to it, favoring a better interaction between the target site and the active site (Cunha and Aguiar 2015).

However, several obstacles are noted in the process of developing new drugs, preventing many molecules from reaching the final stages of the development process due to the problems attributed to their physical-chemical and/or biological characteristics (Santos and Rodrigues 2011; Silva 2016; Knop and Maria 2017). In this sense, new tools have been developed in order to circumvent these problems, with emphasis on in silico analysis, tools that use mathematical and computational methods with proven effectiveness to predict a great diversity of physicochemical and biological characteristics of a molecule in a smaller time and reduced cost (Papa 2017).

In view of the biological potential of 1,2,4-oxadiazoles and the need for new antimicrobials, the work describes the synthesis, antimicrobial activity, and in silico analysis of different (E)-3-(aryl)-5-styryl-1,2,4oxadiazoles.

\section{Material and Methods}

All solvents were purified before use as described in the literature (Perrin and Amarego 1996). $\mathrm{CHCl}_{2}$ and $\mathrm{CHCl}_{3}$ were dried by distillation from $\mathrm{CaH}_{2}$. EtOH was dried by distillation from metallic magnesium. AcOEt and Hexane were distillations from the Vigreux column. All other commercially available solvents and reagents were used without further purification. Reactions were monitored by thin-layer chromatography (TLC) on $0.25 \mathrm{~mm}$ silica gel 60 plates $\left(\mathrm{F}_{254}\right)$ using UV light as a visualizing agent. Column chromatographic purification was performed using silica gel 60 (70-230 mesh) unless indicated otherwise. All compounds purified by crystallization or chromatography were sufficiently pure for use in further experiments unless indicated otherwise.

The IR spectra were recorded on a Fourier Spectrum 400 FT-IR/FT-NIR Spectrometer Model Perkin Elmer, the samples being prepared as thin films or $\mathrm{KBr}$ pellets. ${ }^{1} \mathrm{H}$ NMR data were recorded at $400 \mathrm{MHz}$ using a Varian UNITY PLUS spectrometer. ${ }^{1} \mathrm{H}$ NMR chemical shifts are reported as delta $(\delta)$ units in parts per million $(\mathrm{ppm})$ relative to residual $\mathrm{CDCl}_{3}(7.26 \mathrm{ppm})$ or to the central line of DMSO- $d_{6}(2.50 \mathrm{ppm})$. Coupling constants $(J)$ were reported in Hertz $(\mathrm{Hz}) \cdot{ }^{13} \mathrm{C}$ NMR data were recorded at $100 \mathrm{MHz}$ using a Varian UNITY PLUS spectrometer. ${ }^{13} \mathrm{C} N M R$ chemical shifts were reported as delta $(\delta)$ units in parts per million $(\mathrm{ppm})$ relative to the central line of $\mathrm{CDCl}_{3}$ (77.00 ppm) or DMSO-d ${ }_{6}$ (39.51 ppm).

\section{General procedure for the synthesis of (Z)-aryl-N'-hydroxybenzimidamides 3a-e}

The preparation of (Z)-aryl- $N$ '-hydroxybenzimidamides 3a-e was based on the methodology described by Barros et al. (2011) with some modifications. Hydroxylamine hydrochloride (4.16 g, $60 \mathrm{mmol})$ and sodium carbonate $(3.2 \mathrm{~g} ; 30 \mathrm{mmol})$ in $80 \mathrm{~mL}$ of distilled water at room temperature were dissolved in a $250 \mathrm{~mL}$ round-bottom flask. Then $20.0 \mathrm{mmol}$ of the corresponding different nitriles $2 \mathrm{a}$-e in $80 \mathrm{~mL}$ of ethanol was added. The reaction mixture was placed under stirring at $25^{\circ} \mathrm{C}$ and the end of the reaction was verified by thin layer chromatography (TLC). After completion of the reaction, ethanol was evaporated with the aid of a rotary evaporator for further extraction of the organic phase. The organic phase was extracted from the aqueous medium using ethyl acetate $(2 \times 50 \mathrm{~mL})$ with the aid of the separatory funnel, which was separated and dried with anhydrous sodium sulfate. Then the extraction solvent was filtered off and removed under reduced pressure. The (Z)-aryl- $N^{\prime}$-hydroxybenzimidamides 3a-e were purified by crystallization using the hexane/chloroform (10:90) system. 
(Z)- $N$ '-hydroxybenzimidamide (3a): Yield $80 \%$ (2.16 g); white solid: $\mathrm{mp} 74-76{ }^{\circ} \mathrm{C}$; IR (KBr pellet): 国 $\max$ $687,768,926,1107,1384,1446,1499,1590,1645,2361,2893,3059,3212,3356,3448 \mathrm{~cm}^{-1}$; ${ }^{1} \mathrm{H}$ NMR $(400$ $\left.\mathrm{MHz}, \mathrm{DMSO}-d_{6}\right) \delta 5,81\left(2 \mathrm{H}, \mathrm{s}, \mathrm{NH}_{2}\right), 7.38-7.36\left(3 \mathrm{H}, \mathrm{m}, \mathrm{H}_{\text {Aryl }}\right), 7.69-7.67\left(2 \mathrm{H}, \mathrm{m}, \mathrm{H}_{\text {Aryl }}\right), 9.63(1 \mathrm{H}, \mathrm{s}, \mathrm{OH}) ;{ }^{13} \mathrm{C} \mathrm{NMR}$ $\left(100 \mathrm{MHz}, \mathrm{DMSO}-d_{6}\right) \delta 125.4,128.1,128.9,133.4,150.8$ (Li et. al 2013).

(Z)-N'-hydroxy-3-methylbenzimidamide (3b): Yield 60\% (1.80 g); white solid: $\mathrm{mp} 133-135$ ㅇ; $\mathrm{IR} \mathrm{(KBr}$ pellet): 回max $700,793,892,1085,1389,1586,1647,2360,2921,3039,3200,3357,3454 \mathrm{~cm}^{-1} ;{ }^{1} \mathrm{H}$ NMR $(400$ $\left.\mathrm{MHz}, \mathrm{DMSO}-d_{6}\right) \delta 2.32\left(3 \mathrm{H}, \mathrm{s}, \operatorname{Aryl}-\mathrm{CH}_{3}\right), 5.75\left(2 \mathrm{H}, \mathrm{s}, \mathrm{NH}_{2}\right), 7.21-7.17\left(2 \mathrm{H}, \mathrm{m}, \mathrm{H}_{\text {Aryl }}\right), 7.28-7.27\left(2 \mathrm{H}, \mathrm{m}, \mathrm{H}_{\text {Aryl }}\right)$, $9.57(1 \mathrm{H}, \mathrm{s}, \mathrm{OH}) .{ }^{13} \mathrm{C}$ NMR $\left(100 \mathrm{MHz}, \mathrm{DMSO}-d_{6}\right) \delta 21.1,122,6,125.9,129.5,129.7,133.3,137.1,150.9$ (Andrade et al. 2016).

(Z)-N'-hydroxy-4-methylbenzimidamide (3c): Yield 72\% (2.16 g); white solid: mp 144-146 ㅇ C; IR ( $\mathrm{KBr}$ pellet): 目花 $747,823,936,1099,1391,1418,1588,1664,2916,3049,3367,3500 \mathrm{~cm}^{-1} ;{ }^{1} \mathrm{H} \mathrm{NMR}(400 \mathrm{MHz}$, DMSO- $\left.d_{6}\right) \delta 2.31\left(3 \mathrm{H}, \mathrm{s}, \operatorname{Aryl}-\mathrm{CH}_{3}\right), 5.73\left(2 \mathrm{H}, \mathrm{s}, \mathrm{NH}_{2}\right), 7.17\left(2 \mathrm{H}, \mathrm{d}, J=8.2 \mathrm{~Hz}, \mathrm{H}_{\text {Aryl }}\right), 7.56\left(2 \mathrm{H}, \mathrm{d}, J=8.2 \mathrm{~Hz}, \mathrm{H}_{\text {Aryl }}\right)$, $9.52(1 \mathrm{H}, \mathrm{s}, \mathrm{OH}) ;{ }^{13} \mathrm{C}$ NMR $\left(100 \mathrm{MHz}, \mathrm{DMSO}-d_{6}\right) \delta 20.8,125.3,128.6,130.5,138.2,150.8$ (Andrade et al. 2016).

(Z)-4-chloro-N'-hydroxybenzimidamide (3d): Yield 60\% (2.04 g); white solid: $\mathrm{mp} 128-129$ 우 $\mathrm{IR}(\mathrm{KBr}$ pellet): 国 $\max 722,840,920,1087,1380,1497,1589,1655,1918,2361,2893,3053,3152,3346,3468 \mathrm{~cm}^{-1}$; ${ }^{1} \mathrm{H} \mathrm{NMR}\left(400 \mathrm{MHz}, \mathrm{DMSO}-d_{6}\right) \delta 5.86\left(2 \mathrm{H}, \mathrm{s}, \mathrm{NH}_{2}\right), 7.43\left(2 \mathrm{H}, \mathrm{d}, J=8.6 \mathrm{~Hz}, \mathrm{H}_{\text {Aryl }}\right), 7.69\left(2 \mathrm{H}, \mathrm{d}, J=8.6 \mathrm{~Hz}, \mathrm{H}_{\text {Aryl }}\right)$, $9.73(1 \mathrm{H}, \mathrm{s}, \mathrm{OH}) ;{ }^{13} \mathrm{C}$ NMR $\left(100 \mathrm{MHz}\right.$, DMSO- $d_{6} \delta$ 127.1, 128.1, 133.2, 133.4, 149.9 (Andrade et al. 2016).

(Z)-N'-hydroxy-4-nitrobenzimidamide (3e): Yield 60\% (2.18 g); white solid: $\mathrm{mp}$ 180-181 우 $\mathrm{IR}(\mathrm{KBr}$ pellet): 回 $\max 700,810,860,922,1105,1337,1512,1596,1657,2844,3114,3180,3351, \mathrm{~cm}^{-1} ;{ }^{1} \mathrm{H}$ MNR (400 $\left.\mathrm{MHz}, \mathrm{DMSO}-d_{6}\right) \delta 6.08\left(2 \mathrm{H}, \mathrm{s}, \mathrm{NH}_{2}\right), 7.97\left(2 \mathrm{H}, \mathrm{d}, J=9.0 \mathrm{~Hz}, \mathrm{H}_{\text {Aryl }}\right), 8.25\left(2 \mathrm{H}, \mathrm{d}, J=9.0 \mathrm{~Hz}, \mathrm{H}_{\text {Aryl }}\right), 10.16(1 \mathrm{H}, \mathrm{s}$, $\mathrm{OH}) ;{ }^{13} \mathrm{C}$ NMR $\left(100 \mathrm{MHz}\right.$, DMSO- $\left.d_{6}\right) \delta 123.4,126.4,139.5,147.5,149.4$ (Andrade et al. 2016).

\section{Procedure for the synthesis of the ethyl $(E)$-cinnamate}

(E)-cinnamic acid ( $4.44 \mathrm{~g}, 30 \mathrm{mmol})$, ethanol $(50 \mathrm{ml})$, and sulfuric acid $(0.16 \mathrm{~mL} ; 3 \mathrm{mmol})$ were refluxed for 24 hours. The advancement of the reaction was monitored by thin layer chromatography (TLC). Then the reaction, excess alcohol was removed under reduced pressure and the residue was extracted with ethyl acetate. The ethyl acetate extract was washed with a solution of sodium bicarbonate and subsequently with distilled water, dried over anhydrous sodium sulfate and concentrated in vacuo to yield the crude product, which was purified by column chromatography (hexanes/ethyl acetate, 97.5:2.5) to give the desired ethyl (E)-cinnamate ( $313.28 \mathrm{mg}, 90 \%$ yield).

Ethyl (E)-cinnamate: Yield 90\% (4.75 g); colorless oil; IR (KBr pellet): 国 $\max _{\max } 1258,1270,1326,1638$, 1712, 2904, 2981, $3062 \mathrm{~cm}^{-1} ;{ }^{1} \mathrm{H}$ NMR $\left(300 \mathrm{MHz}, \mathrm{CDCl}_{3}\right) \delta 1.35(3 \mathrm{H}, \mathrm{t}, J=7.2 \mathrm{~Hz}), 4.28(2 \mathrm{H}, \mathrm{q} J=7.2 \mathrm{~Hz}), 6.45$ $\left(1 \mathrm{H}, \mathrm{d}, J=15.6 \mathrm{~Hz}, \mathrm{H}_{\text {Vinylic }}\right), 7.40-7.38\left(3 \mathrm{H}, \mathrm{m}, \mathrm{H}_{\text {Aryl }}\right), 7.55-7.52\left(2 \mathrm{H}, \mathrm{m}, \mathrm{H}_{\text {Aryl }}\right), 7.70\left(1 \mathrm{H}, \mathrm{d}, J=15,6, \mathrm{H}_{\text {Vinylic }}\right) ;{ }^{13} \mathrm{C}$ $\operatorname{NMR}\left(75 \mathrm{MHz}, \mathrm{CDCl}_{3}\right) \delta 13.9,60.1,117.84,127.61,128.43,129.77,134.04,144.13,166.5$ (Sarvi et al. 2018).

\section{Procedure for the synthesis of the (E)-3-(aryl)-5-styryl-1,2,4-oxadiazoles}

A mixture of (E)-cinnamic acid $4(0.222 \mathrm{~g}, 1.50 \mathrm{mmol})$, appropriate (Z)-aryl- $N^{\prime}$ hydroxybenzimidamides $3 a-e(2.00 \mathrm{mmol})$ and $\mathrm{K}_{2} \mathrm{CO}_{3}(0.24 \mathrm{~g}, 1.70 \mathrm{mmol})$ was well triturated and placed in a small glass test tube followed by irradiation in a domestic microwave oven ( $650 \mathrm{~W}, 100 \%$ potency) for 15 $26 \mathrm{~min}$ and then cooled. After that, the crude product was purified by chromatography on silica gel using hexanes/ethyl acetate (90:10) to yield the corresponding (E)-3-(aryl)-5-styryl-1,2,4-oxadiazoles 5a-e.

(E)-3-phenyl-5-styryl-1,2,4-oxadiazole (5a): Yield 65\% (0.32 g); white solid. ${ }^{1} \mathrm{H} \mathrm{NMR}\left(400 \mathrm{MHz}, \mathrm{CDCl}_{3}\right)$ 国 8.15-8.12 $\left(2 \mathrm{H}, \mathrm{m}, \mathrm{H}_{\text {Heteroaryl }}\right) ; 7.07\left(1 \mathrm{H}, \mathrm{d}, J=16.8 \mathrm{~Hz}, \mathrm{H}_{\text {Vinylic }}\right), 7.43\left(3 \mathrm{H}, \mathrm{m}, \mathrm{H}_{\text {Heteroaryl }}\right), 7.50\left(3 \mathrm{H}, \mathrm{m}, \mathrm{H}_{\text {Heteroaryl }}\right)$, $7.61\left(2 \mathrm{H}, \mathrm{m}, \mathrm{H}_{\text {Heteroaryl }}\right), 7.89\left(1 \mathrm{H}, \mathrm{d}, J=16.4 \mathrm{~Hz}, \mathrm{H}_{\text {Vinylic }}\right) ;{ }^{13} \mathrm{C}$ NMR $\left(100 \mathrm{MHz}, \mathrm{CDCl}_{3}\right)$ 回 110.22, 126.92, 127.42, 127.89, 128.81, 129.03, 130.48, 131.11, 134.39, 142.65, 168.69, 175.19 (Pankrateva et al. 2017).

(E)-5-styryl-3-(m-tolyl)-1,2,4-oxadiazole (5b): Yield 61\% (0.30 g); white solid. ${ }^{1} \mathrm{H}$ NMR (400 MHz, $\left.\mathrm{CDCl}_{3}\right)$ ? $2.44\left(3 \mathrm{H}, \mathrm{s}, \mathrm{CH}_{3}\right), 7.07\left(1 \mathrm{H}, \mathrm{d}, J=16.4 \mathrm{~Hz}, \mathrm{H}_{\text {Vinylic }}\right), 7.46-7.31\left(5 \mathrm{H}, \mathrm{m}, \mathrm{H}_{\text {Heteroaryl }}\right), 7.61\left(2 \mathrm{H}, \mathrm{m}, \mathrm{H}_{\text {Heteroaryl }}\right)$, 7.95-7.90 (3H, m, H Heteroaryl); ${ }^{13} \mathrm{C}$ NMR $\left(100 \mathrm{MHz}, \mathrm{CDCl}_{3}\right)$ 回 21.31, 110.23, 124.54, 126.75, 127.88, 127.97, $128.74,129.04,130.48,131.91,134.41,138.62,142.61,168.78,175.12$. 
(E)-5-styryl-3-(p-tolyl)-1,2,4-oxadiazole (5c): Yield 60\% (0.30 g); white solid. ${ }^{1} \mathrm{H} N M R\left(400 \mathrm{MHz}, \mathrm{CDCl}_{3}\right)$ ] $2.41\left(3 \mathrm{H}, \mathrm{s}, \mathrm{CH}_{3}\right), 7.07\left(1 \mathrm{H}, \mathrm{d}, J=16.4 \mathrm{~Hz}, \mathrm{H}_{\text {Vinylic }}\right), 7.30\left(2 \mathrm{H}, \mathrm{d}, J=7.6 \mathrm{~Hz}, \mathrm{H}_{\text {Heteroaryl }}\right), 7.44-7.40(3 \mathrm{H}, \mathrm{m}$, $\left.\mathrm{H}_{\text {Heteroaryl }}\right), 7.60\left(2 \mathrm{H}, \mathrm{m}, \mathrm{H}_{\text {Heteroaryl }}\right), 7.89\left(1 \mathrm{H}, \mathrm{d}, J=16.0 \mathrm{~Hz}, \mathrm{H}_{\text {Vinylic }}\right), 8.02\left(2 \mathrm{H}, \mathrm{d}, J=8.4 \mathrm{~Hz}, \mathrm{H}_{\text {Heteroaryl }}\right) ;{ }^{13} \mathrm{C}$ NMR $\left(100 \mathrm{MHz}, \mathrm{CDCl}_{3}\right)$ 国 21.54, 110.28, 124.09, 127.33, 127.87, 129.03, 129.53, 130.44, 134.43, 141.43, 142.51, 168.69, 175.03 (Beletskii et al. 2017).

(E)-3-(4-chlorophenyl)-5-styryl-1,2,4-oxadiazole (5d): Yield 66\% (0.36 g); white solid. ${ }^{1} \mathrm{H}$ NMR (400 $\left.\mathrm{MHz}, \mathrm{CDCl}_{3}\right)$ ? $7.07\left(1 \mathrm{H}, \mathrm{d}, J=16.4 \mathrm{~Hz}, \mathrm{H}_{\text {Vinylic }}\right), 7.49-7.42\left(5 \mathrm{H}, \mathrm{m}, \mathrm{H}_{\text {Heteroaryl }}\right), 7.62\left(2 \mathrm{H}, \mathrm{m}, \mathrm{H}_{\text {Heteroaryl }}\right), 7.90(1 \mathrm{H}$, $\left.\mathrm{d}, J=16.4 \mathrm{~Hz}, \mathrm{H}_{\text {Vinylic }}\right), 8.07\left(2 \mathrm{H}, \mathrm{d}, J=8.4 \mathrm{~Hz}, \mathrm{H}_{\text {Heteroaryl }}\right) ;{ }^{13} \mathrm{C} \mathrm{NMR}\left(100 \mathrm{MHz}, \mathrm{CDCl}_{3}\right)$ 目 110.03, 125.45, 127.94, $128.73,128.80,129.07,129.15,129.19,129.42,129.54,130.60,134.32,137.27,142.94,167.89,175.40$ (Ryu et al. 2001).

(E)-3-(4-nitrophenyl)-5-styryl-1,2,4-oxadiazole (5e): Yield $12 \%$ (0.06 g); white solid. ${ }^{1} \mathrm{H}$ NMR (400 MHz, $\left.\mathrm{CDCl}_{3}\right)$ [ㄹ?]? $7.10\left(1 \mathrm{H}, \mathrm{d}, J=16.4 \mathrm{~Hz}, \mathrm{H}_{\text {Vinylic }}\right), 7.45\left(3 \mathrm{H}, \mathrm{m}, \mathrm{H}_{\text {Heteroaryl }}\right), 7.62\left(2 \mathrm{H}, \mathrm{m}, \mathrm{H}_{\text {Heteroaryl }}\right), 7.95(1 \mathrm{H}, \mathrm{d}, J=16.4$

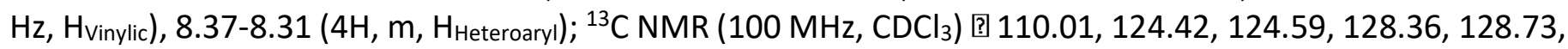
$129.46,131.17,133.22,133.76,134.48,143.93,149.77,167.50,176.34$.

\section{In vitro assay for antimicrobial activity}

The antimicrobial potential of (E)-3-(aryl)-5-styryl-1,2,4-oxadiazoles 5a-e was evaluated against the bacteria Enterococcus faecalis (UFPEDA 138), Escherichia coli (UFPEDA 224), Pseudomonas aeruginosa (416) and Staphylococcus aureus (UFPEDA 02), and the fungi Candida utilis (UFPEDA 1009). The microorganisms were maintained in nutrient agar (NA), stored at $4{ }^{\circ} \mathrm{C}$. The antimicrobial activity evaluation was performed by determination of the values of minimum inhibitory concentrations (MIC) as previously (Silva et al. 2016; Rocha et al. 2016). The antimicrobials Metronidazole and Fluconazole were used as a positive control.

\section{In silico studies of (E)-3-(aryl)-5-styryl-1,2,4-oxadiazoles}

The values of consensus Log $\mathrm{P}_{\mathrm{o} / \mathrm{w}}(\mathrm{cLog} \mathrm{P})$, molecular weight (MW), $\mathrm{N}^{\circ} \mathrm{H}$-bond acceptors (nHBA), $\mathrm{N}^{\circ}$ $\mathrm{H}$-bond donors ( $\mathrm{nHBD}$ ), $\mathrm{N}^{\circ}$ of violations of Lipinski's rule, gastrointestinal absorption, and blood-brain barrier permeant were calculated using SwissADME provided by the Swiss Institute of Bioinformatics (Daina et al. 2017).

Through the Osiris Property Explorer program, a free program (https://www.organicchemistry.org/prog/peo/), information was obtained regarding the chronic toxicity of compounds 5a-e, with the result being classified in the program interface through colors, in which the red color indicates high risk, the yellow color moderate risk, and the low-risk green color. The calculated values of Druglikeness and Drug score were also obtained from the same program.

The PASS online platform was used to survey the possible biological activities of compounds 5a-e, evaluating more than 3500 potential biological activities, including pharmacological effects, interaction with metabolic enzymes and transporters, toxic and adverse effects, mechanisms of action, action toxicological for some organisms, such as protozoa, microorganisms, and aquatic and terrestrial organisms related to environmental impact, among other information (Oliveira 2014).

\section{Results and Discussion}

This work describes the synthesis, characterization, antimicrobial evaluation and in silico studies of (E)-3-(aryl)-5-styryl-1,2,4-oxadiazoles derived from the cinnamic acid a natural product. Figure 1 shows the general strategy employed in the preparation of these 1,2,4-oxadiazole compounds. Initially, arylnitriles (1) were converted into the corresponding (Z)-aryl- $N$ '-hydroxybenzimidamide (2), which were subjected to an $O$-acylamidoxime reaction followed by dehydration, using the ethyl $(E)$-cinnamate $(4)$ derivative $(E)$-cinnamic acid (3), providing the desired (E)-3-(aryl)-5-styryl-1,2,4-oxadiazoles (5). 


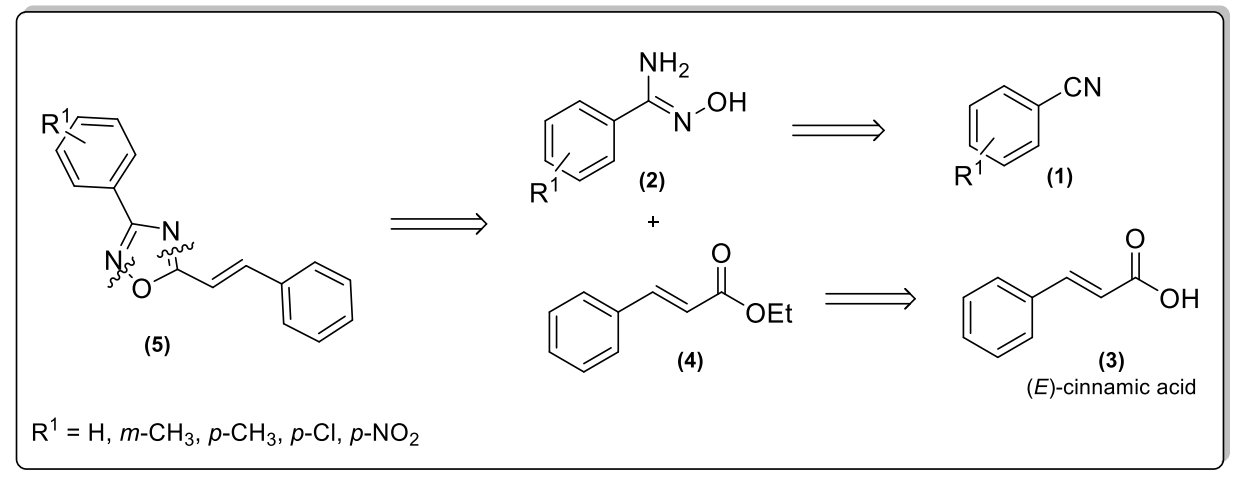

Figure 1. The retrosynthetic strategy of 1,2,4-oxadiazole compounds (5).

\section{Synthesis and characterization of (E)-3-(aryl)-5-styryl-1,2,4-oxadiazoles}

The (E)-3-(aryl)-5-styryl-1,2,4-oxadiazoles (5a-e) were obtained after three steps, by incorporating the 1,2,4-oxadiazolic unit in the structure of the natural product cinnamic acid (3), as shown in Figure 2. Initially, (Z)-aryl-N'-hydroxybenzimidamide (2a-e) were prepared from the reaction between arylnitrile (1ae) and hydroxylamine hydrochloride in a hydroethanolic medium. In parallel, the ethyl (E)-cinnamate (4) was prepared from the esterification reaction of $(E)$-cinnamic acid (3). Subsequently, the $O$-acylamidoxime reaction was performed, followed by dehydration, providing the desired compounds (5a-e).

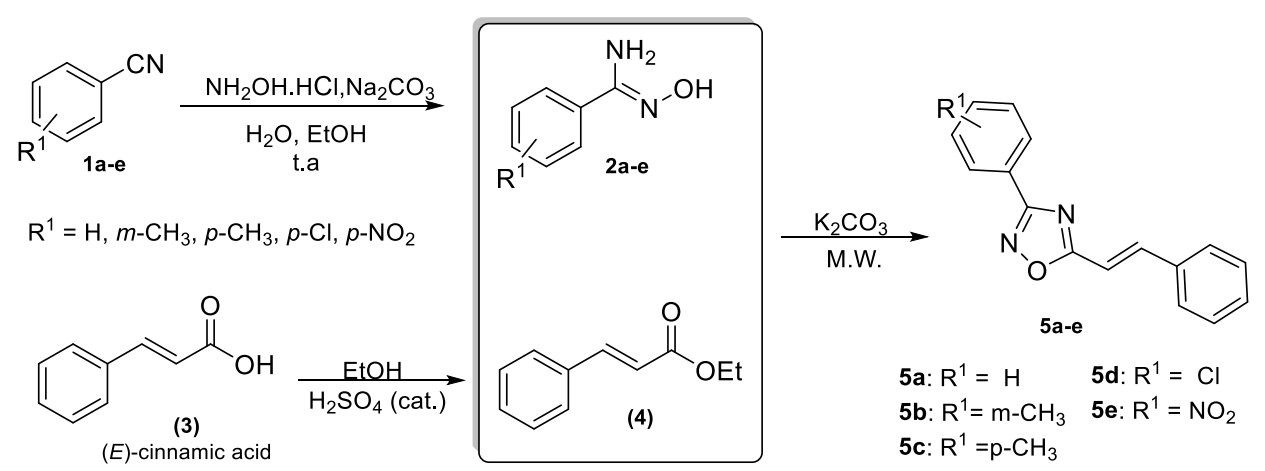

Figure 2. Reaction steps involved in the synthesis of compounds 5a-e.

The first stage provided compounds $2 a-e$ with reaction times ranging from 20 to 48 hours and with good yields after recrystallization (Figure 3). Additionally, the characterization of compounds 2a-e is in accordance with the data described in the literature (Li et al. 2013; Andrade et al. 2016).

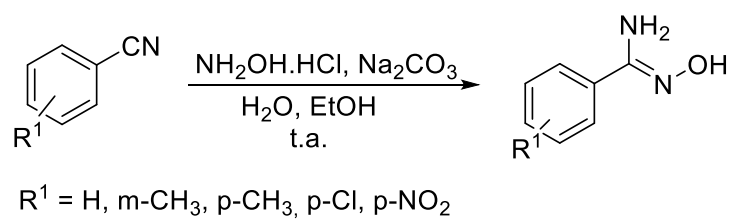

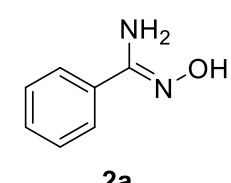

2a

$22 \mathrm{~h}, 80 \%$

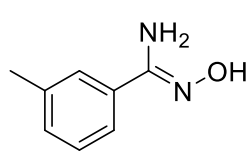

2b 41h, $60 \%$<smiles>Cc1ccc(/C(N)=N/O)cc1</smiles>

$2 \mathrm{c}$ 24h, $72 \%$<smiles>N/C(=N\O)c1ccc(Cl)cc1</smiles>

2d



$48 \mathrm{~h}, 60 \%$

Figure 3. Synthesis of the (Z)-aryl- $N$ '-hydroxybenzimidamide 2a-e.

Compound 2e was obtained in a longer reaction time, which probably indicates that electronic factors influence this reaction. Furthermore, it was observed that the position of the substituent also influences this reaction, since compounds $2 \mathrm{~b}$ and $2 \mathrm{c}$ showed different reaction times and yields, and in the target position it led to compound $2 \mathrm{~b}$ the longest reaction time and the lowest yield. In general, compounds $2 \mathrm{a}$-e were obtained with yields that were in the range of $50-80 \%$. 
The second step provided compound 4 with a $90 \%$ yield after 24 hours of reaction. The spectroscopic data of compound 4 are in accordance with those described by Sarvi et al. (2018). The last reaction step provided compounds $5 a-e$ in yields ranging from moderate to good after purification by chromatographic column (Table 1).

Table 1. Synthesis of compounds 5a-e.

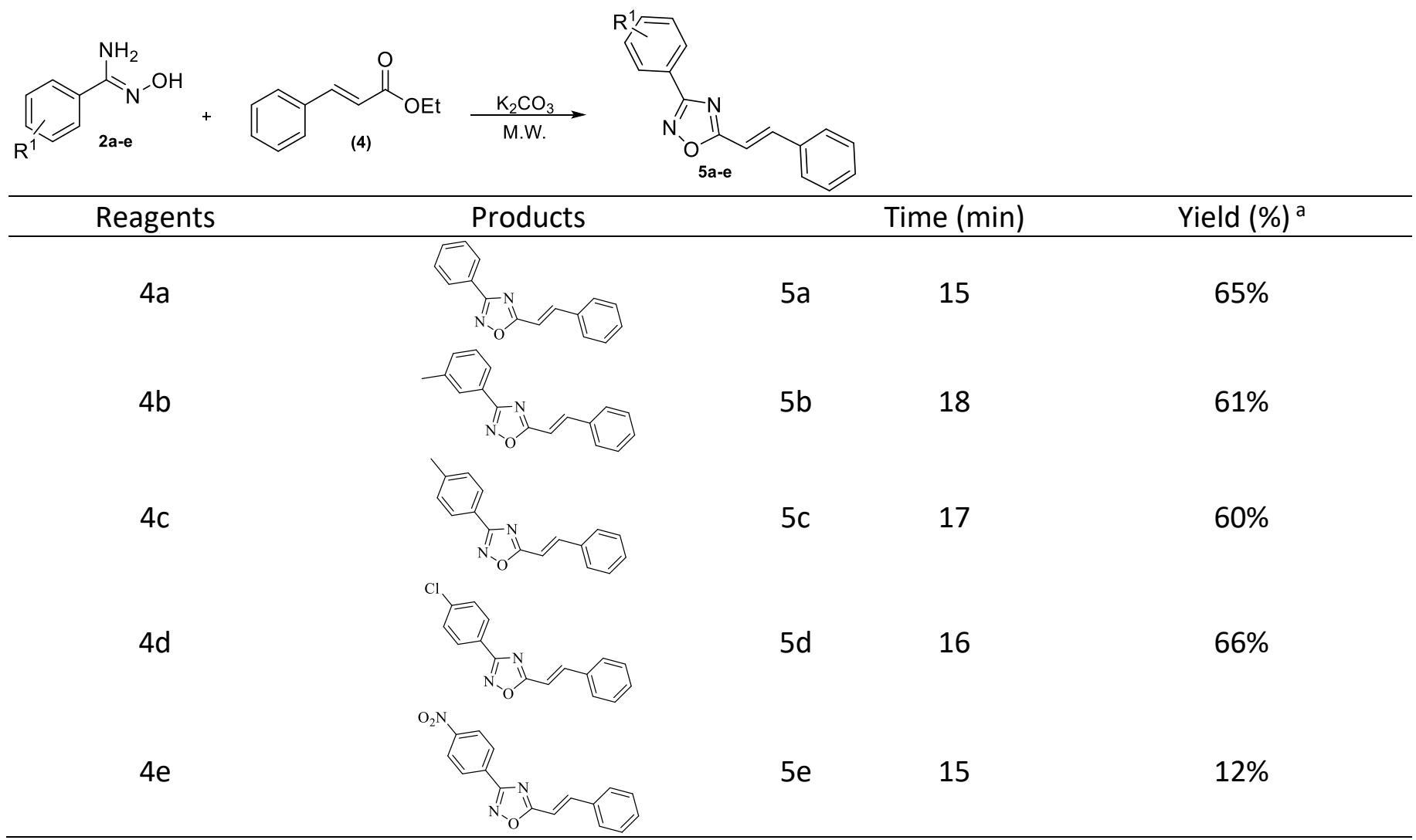

a Isolated product.

In general, the methodology used for the formation of (E)-3-(aryl)-5-styryl-1,2,4-oxadiazoles 5a-e proved to be fast and efficient, taking into account that there is a diverse number of processes that allow the preparation of 1,2,4-oxadiazoles, which present some disadvantages, such as the use of high temperature, long reaction times and the use of hazardous solvents such as dimethylformamide, diglyme, and 1,4-dioxane (Sauer et al. 2019). In addition, the reaction for the formation of (E)-3-(aryl)-5-styryl-1,2,4oxadiazoles 5a-e had little influence on the substrates used, since the compounds 5a-e obtained did not show significant variations in reaction time and yield, except for compound $5 \mathrm{e}$, which had the lowest value income (Table 1).

According to the analysis of the ${ }^{1} \mathrm{H}$ NMR spectra of compounds 5a-e, two signals were observed with a multiplicity of the doublet type of integral equal to 1, with chemical displacement at 7.07-7.10 and 7.89$7.95 \mathrm{ppm}$ presenting a coupling constant with a value equal to $16.4 \mathrm{~Hz}$. This signal was attributed to the vinyl hydrogen indicating the maintenance of the double bond with $(E)$-geometry. In addition, in the ${ }^{13} \mathrm{C} N \mathrm{NM}$ spectra of the compounds 5a-e, two signals with chemical shifts of 175.0-176.3 and 167.5-168.7 ppm were observed, which are characteristic of the $C_{s p 2}$ carbons of the oxadiazole ring, as described in the literature (Zakeri et al. 2013; Barros et al. 2014). Therefore, these signs indicate the formation of compounds 5a-e.

\section{Antimicrobial activity}

The growing need for new antimicrobial agents, driven mainly by the frequent cases of resistant microorganisms, has fostered the constant search for molecules that can be applied to obtain new effective therapeutic agents (Lee and Lee 2018). In this context, the tests to obtain the MIC values of the compounds under development have stood out as quantitative measures of high reliability and safety, to evaluate substances with possible antimicrobial activity in vitro (Zorzi 2013). In view of the above, compounds 5a-e 
were submitted to the evaluation of their antimicrobial properties against the bacteria Enterococcus faecalis (UFPEDA 138), Escherichia coli (UFPEDA 224), Pseudomonas aeruginosa (UFPEDA 416) and Staphylococcus aureus (UFPEDA 02), and the fungus Candida utilis (UFPEDA 1009), representing the MIC values at the lowest concentration capable of visually inhibiting $100 \%$ of microbial growth (Espinel-Ingroff et al. 2005). These microorganisms were selected due to their clinical importance and involvement in antimicrobial resistance events (Prestinaci et al. 2015). The results obtained are shown in Table 1.

Table 2. Antimicrobial activity of compounds 5a-e represented by the minimum inhibitory concentration (MIC) in $\mu \mathrm{g} / \mathrm{mL}$.

\begin{tabular}{|c|c|c|c|c|c|}
\hline \multirow{2}{*}{ Compound } & \multicolumn{4}{|c|}{ Bacteria } & \multirow{2}{*}{$\begin{array}{l}\text { Fungi } \\
\text { C. utilis }\end{array}$} \\
\hline & Saureus & E. faecalis & E. coli & P. aeruginosa & \\
\hline $5 a$ & + & + & + & 2500 & 312,5 \\
\hline $5 b$ & + & + & + & + & 625 \\
\hline $5 c$ & + & + & + & + & 2500 \\
\hline $5 d$ & + & + & + & 2500 & 625 \\
\hline $5 e$ & + & + & + & 2500 & 625 \\
\hline
\end{tabular}

$(+)$ denotes bacterial growth.

According to Table 2, compounds 5a-e showed low antimicrobial activity, being active only against the strain of $P$. aeruginosa with MIC values of $2500 \mu \mathrm{g} / \mathrm{mL}$ for some of the tested compounds. Regarding antifungal activity, all compounds were shown to be active against the $C$. utilis strain, with the lowest MIC value for compound $5 \mathrm{a}(312.5 \mu \mathrm{g} / \mathrm{mL})$. According to Morales et al. (2008), good antimicrobial activity is considered when MIC values are in the $50-500 \mu \mathrm{g} / \mathrm{mL}$ range, moderate activity for the $500-1500 \mu \mathrm{g} / \mathrm{mL}$ range and activity low to values above $1500 \mu \mathrm{g} / \mathrm{mL}$. Thus, it is possible to conclude that compound 5a showed good antifungal activity, whereas compound $5 c$ showed low activity. The compounds $5 b, 5 d$ and 5 e evaluated showed moderate antifungal activity.

Tale et al. (2011) reported results that are similar to those described in this work when evaluating the antimicrobial activity of 1,2,4-oxadiazoles against different fungal and bacterial strains. However, Tale et al. (2011) obtained some oxadiazolic derivatives that showed MIC values from 10 to $50 \mu \mathrm{g} / \mathrm{mL}$, both for fungal and bacterial strains, in line with the drugs used as standards (ciprofloxan and miconazole).

Low MIC values against different fungal strains have also been reported by Sangshetti et al. (2009) when exploring the antifungal activity of novel 3-(1-(1-substituted piperidin-4-yl)-1H-1,2,3-triazol-4-yl)1,2,4-oxadiazol-5(4H)-one. These compounds also proved to be active against the genus Candida, in addition to other fungal strains.

Additionally, it is possible to notice a tendency of compounds 5a-e to present targeted antifungal activity, not having a considerable impact on bacterial strains. This fact may indicate a selectivity in the antimicrobial action of these compounds, a benefit that is often absent in commercial antimicrobials, which allows a treatment that does not significantly affect the normal microbiota that protects the host, thus preventing the development of considerable adverse effects (Murray et al. 2015).

The activity of compounds 5a-e against $P$. aeruginosa is extremely relevant since this microorganism is one of the main causes of nosocomial infections in Brazilian hospitals. In addition, this pathogen stands out for its resistance to clinical antibiotics and high morbidity and mortality rates (Neves et al. 2011; Digiandomenico et al. 2017).

The activity of compounds 5a-e against $C$. utilis, is of great importance, given the high clinical importance of this species, since it is involved in diverse infectious conditions (Sidrim and Rocha 2010; Irfan et al. 2017; Varano et al. 2019). These results allow us to conjecture that compounds 5a-e are a promising class for further studies that may collaborate in the enhancement of their activities, as well as elucidating their likely mechanisms of action. Thus, different in silico studies were carried out in order to carry out a theoretical survey of the pharmacological, toxicological, and chemical characteristics of compounds 5a-e to identify promising characteristics. 


\section{In silico studies}

In silico models consist of methods executed on a computer, or through computer simulation, which stands out as alternatives to other already existing methodologies, since they present as advantages a shorter analysis time, speed, reproducibility, accuracy, and absence of the use of vertebrate animals. These methods are based on human bioregulatory models to generate information regarding the pharmacodynamic, pharmacokinetic, and toxicological characteristics of the tested molecules, in addition to other possible uses (Santos 2011; Srinivas et al. 2014).

In order to identify promising characteristics that encourage the development of more advanced studies involving compounds 5a-e, a survey of the pharmacokinetic, toxicological, and chemical characteristics of these compounds was carried out using the SwissADME and Osiris Property Explorer platforms. The results are summarized in Table 3.

Table 3. Pharmacokinetic, toxicological, and chemical properties in silico of compounds 5a-e.

\begin{tabular}{cccccc}
\hline Properties & \multicolumn{5}{c}{ Compounds } \\
\cline { 2 - 6 } & $5 \mathrm{a}$ & $5 \mathrm{~b}$ & $5 \mathrm{c}$ & $5 \mathrm{~d}$ & $5 \mathrm{e}$ \\
\hline cLogP & 3.68 & 3.98 & 4.01 & 4.18 & 3.05 \\
MW & 248.28 & 262.31 & 262.31 & 282.72 & 293.28 \\
nHBD & 0 & 0 & 0 & 0 & 0 \\
nHBA & 3 & 3 & 3 & 3 & 5 \\
Lipinski & 0 & 0 & 0 & 0 & 0 \\
Gl absorption & High & High & High & High & High \\
BBB permeant & Yes & Yes & Yes & Yes & No \\
Chronic toxicity & Low risk & Low risk & Low risk & Low risk & Low risk \\
Druglikeness & 0.65 & -0.01 & -1.07 & 1.29 & -9.91 \\
Drug score & 0.57 & 0.47 & 0.39 & 0.50 & 0.34 \\
\hline
\end{tabular}

Subtitle: cLogP: Consensus Log $\mathrm{Po}_{\mathrm{o} / \mathrm{w}} ; \mathrm{MW}$ : Molecular weight; $\mathrm{nHBD:} \mathrm{N}^{\circ} \mathrm{H}$-bond donors; nHBA: $\mathrm{N}^{\circ} \mathrm{H}$-bond acceptors; Lipinski: $\mathrm{N}^{\circ}$ of violations of Lipinski's rule; GI absorption: Gastrointestinal absorption; BBB permeant: Blood-brain barrier permeant.

The first point to be discussed is the lipophilicity patterns of compounds 5a-e expressed by the cLogP values. In order to be well absorbed and reach their site of action, drugs must have LogP values within an ideal lipophilicity range, which varies depending on the author (Barreiro and Fraga 2014). When analyzing 2,245 drugs that showed good standards of oral bioavailability, Lipinski et al. (1997) determined that the ideal lipophilicity range comprises CLogP values less than 5 . Thus, it is possible to notice that compounds $5 a-$ e have good values of lipophilicity, pointing out the probability of good pharmacokinetic behavior.

Lipinski (2004) also developed the so-called "Rule of Five", a concept that is widely disseminated and used routinely in new drug discovery protocols. This rule establishes, based on practical observations, a set of physical-chemical parameters that determine whether a drug will present a good oral bioavailability, which are: Present molecular mass (MW) less than 500 Daltons, partition coefficient (cLogP) less than five, maximum of ten $\mathrm{H}$-bond acceptor groups (nHBA) and maximum of five $\mathrm{H}$-bond donor groups (nHBD). The results shown in Table 3 indicate that compounds 5a-e satisfy all of these requirements indicating excellent potential for oral bioavailability, which is of great importance, since this route of administration brings unique benefits, such as convenience, low cost, possibility self-administration, greater adherence to treatment and lower risk of triggering systemic infections in the user (Golan et al. 2014).

The analyzes performed on the SwissADME platform, as proposed by Daina and Zoete (2016), also showed a high gastrointestinal absorption potential for these compounds, corroborating oral bioavailability patterns pointed out by the Lipinski Rule of Five. In addition to gastrointestinal absorption, another important parameter is the pharmacokinetic behavior in accessing the central nervous system from the blood-brain barrier (BBB). The platform pointed out that compounds $5 a-d$ are likely to permeate BBB, an important factor to be considered in the development of a new drug, as it allows it to have access to the central nervous system and is capable of acting on diseases that involve this system (Daina and Zoete 2016).

With the help of Osiris Property Explorer, the probability of these molecules showing mutagenicity, tumorigenicity, irritability, and interference in human reproduction, typical effects of chronic toxicity, was 
evaluated. The compounds 5a-e had a low risk of chronic toxicity, similar to that observed for most drugs since toxicity patterns are among the main parameters involved in the discontinuation of studies involving drug candidates (Moda 2011).

Still, with the help of Osiris Property Explorer, the values of Druglikeness and Drug score were calculated, parameters that express the probability of a molecule becoming a new drug based on its physicalchemical and biological characteristics, as well as its similarity with other molecules marketed. It is worth mentioning that good drug candidates should have Druglikeness values greater than 0 and Drug Score values close to 1 . Thus, the compounds 5a-e showed results, with values varying from moderate to good, indicating a good probability of these compounds becoming good drugs in the future.

In addition to chemical and pharmacokinetic analyzes, a survey of other possible biological activities of the compounds 5a-e was carried out using the PASS online platform, which analyzes more than 3,500 biological activities, being expressed in probability values "of being active" (Pa) (Oliveira 2014). The most prominent activity pointed out for the compounds 5a-e was anxiolytic, in which the values indicate a probability varying between $76.3 \%$ to $86.2 \%$ of these compounds to perform such action. The compound $5 \mathrm{e}$ had a low probability of having anxiolytic effects ( $\mathrm{Pa}=52.3 \%)$, which can be justified by the fact that its physical-chemical characteristics indicate an inability to access the central nervous system, as shown by the SwissADME platform (Table 3) (Rang et al. 2016).

These results corroborate the studies that address the anxiolytic properties of other oxadiazolic derivatives (Singh et al. 2012; Brotschi et al. 2019). Faizi et al. (2012) demonstrated the anxiolytic activity of oxadiazolic derivatives, suggesting experimentally that these compounds would act as GABA receptor agonists in a similar way to drugs used for this purpose, such as benzodiazepines. These authors also demonstrated that the oxadiazoles obtained were compatible with the main benzodiazepine pharmacophores.

Other promising activities were pointed out by the PASS online platform, citing the action in Phobic disorders treatment (Pa values ranging from $42.1 \%$ to $82.2 \%$ ), antidiabetic (Pa values ranging from $39.3 \%$ to $62.2 \%$ ), antiemetic (Pa values ranging from $35.1 \%$ to $52.2 \%$ ) and antiprotozoal (Pa values ranging from $42.3 \%$ to $52.9 \%)$.

These results indicate that the synthesized compounds 5a-e are promising, marking the first steps in the process of discovering new drugs and encouraging the development of future studies involving such molecules as well as their derivatives.

\section{Conclusions}

In general, five (Z)-aryl- $N$ '-hydroxybenzimidamides were synthesized with yields that were in the range of 60 to $80 \%$ while the ethyl $(E)$-cinnamate was obtained with $90 \%$ yield. Additionally, the compounds containing the 1,2,4-oxadiazolic nucleus were synthesized in short reaction times and yields in excess of $60 \%$. The synthesized oxadiazoles showed a reduced spectrum of action since they were active only against Gramnegative bacteria $P$. aeruginosa and the fungus $C$. utilis. These results are in line with the development of structures capable of acting in the treatment of specific infections, considering their reduced spectrum of action, requiring more research to improve their performance, as well as elucidate their mechanism of action.

The different in silico studies have shown promising properties for the synthesized oxadiazoles, pointing out a high probability of these molecules being well absorbed after an oral administration, besides being able to reach the central nervous system performing different actions. In addition, there are strong physicochemical indications that support the likelihood of these compounds presenting anxiolytic, antidiabetic, antiemetic, and antiprotozoal activity.

These results mark one of the most important stages in the development of new drugs, the prospecting for new bioactive molecules, encouraging the development of future studies that can assist in the optimization of the demonstrated antimicrobial activity of these compounds, as well as assessing other possible activities that these molecules and their derivatives may develop, thus contributing to the implementation of new therapeutic agents. 
Authors' Contributions: LIMA, J.A.C.: analysis and interpretation of data; COSTA, E.C.S.: analysis and interpretation of data; BEZERRA, G.B.: acquisition of data, analysis and interpretation of data; CAIANA, R.R.A.: acquisition of data, analysis and interpretation of data; FREITAS FILHO, J.R.: conception and design, acquisition of data, drafting the article; FREITAS, J.C.R.: conception and design, acquisition of data, drafting the article. All authors have read and approved the final version of the manuscript.

Conflicts of Interest: The authors declare no conflicts of interest.

Ethics Approval: Not applicable.

Acknowledgments: The authors would like to thank the funding for the realization of this study provided by the Brazilian agencies PRONEM/FACEPE (Programa de Apoio a Núcleos Emergentes/Fundação de Amparo a Ciência e Tecnologia de Pernambuco - Brasil), Finance Code APQ-0476-1.06/14, CAPES (Coordenação de Aperfeiçoamento de Pessoal de Nível Superior - Brasil), Finance Code 001, and CNPq (Conselho Nacional de Desenvolvimento Científico e Tecnológico - Brasil), Finance Code 434012/2018-1. The authors are also grateful to the Analytical Center of the Department of Fundamental Chemistry at the Federal University of Pernambuco for the analysis of the synthesized compounds.

\section{References}

ANDRADE, D., FREITAS FILHO, J.R. and FREITAS, J.C.R. Aplicação de amidoximas como catalisadores da reação de alilação por aliltrifluoroborato de potássio em meio bifásico. Quimica Nova. 2016, 39(10), 1225-1235. https://doi.org/10.21577/0100-4042.20160158

BARREIRO, E.J. and FRAGA, C.A.M. Química Medicinal: As bases moleculares da ação dos fármacos. 3rd ed. Porto Alegre: Artmed, 2014.

BARROS, C.J.P., FREITAS, J.J.R., OLIVEIRA, R.N. and FREITAS FILHO, J.R. Synthesis of amidoximes using an efficient and rapid ultrasound method. Journal of the Chilean Chemical Society. 2011, 56, 721-722. http://dx.doi.org/10.4067/S0717-97072011000200022

BARROS, C.J.P., et al. Convenient synthesis and cytotoxic activity of 3-aryl-5-pentyl-1,2,4-oxadiazoles from carboxylic acid esters and arylamidoximes under solvent-free conditions. Journal of the Chilean Chemical Society. 2014, 59(1), 2359-2362.

http://dx.doi.org/10.4067/S0717-97072014000100024

BELETSKII, E.V., IGNATENKO, O.A., KUZNETSOV, M.A. and SELIVANOV, S.I. Oxidative addition of N-aminophthalimide to styryl-1,2,4oxadiazoles. Russian Journal of Organic Chemistry. 2010, 46(5), 678-684. http://dx.doi.org/10.1134/s1070428010050143

BROTSCHI, C., et al. Oxadiazole Derivatives as Dual Orexin Receptor Antagonists: Synthesis, Structure-Activity Relationships, and SleepPromoting Properties in Rats. ChemMedChem. 2019, 14, 1257-1270. http://dx.doi.org/10.1002/cmdc.201900242

CUNHA, F.S. and AGUIAR, A.P. Síntese e Bioatividade de 1,2,4-Oxadiazóis. Revista Virtual Química. 2015, 7(6), 2509-2530.

http://dx.doi.org/10.5935/1984-6835.20150150

DAINA, A., MICHIELIN, O. and ZOETE, V. SwissADME: a free web tool to evaluate pharmacokinetics, druglikeness and medicinal chemistry friendliness of small molecules. Scientific Reports. 2017, 7(1), 42717. http://dx.doi.org/10.1038/srep42717

DAINA, A., ZOETE, V. A BOILED-Egg to predict gastrointestinal absorption and brain penetration of small molecules. ChemMedChem. 2016, 11(11), 1117-1121. http://dx.doi.org/10.1002/cmdc.201600182

DIGIANDOMENICO, A., et al. Protective activity of medi3902 for the prevention or treatment of lethal pneumonia and bloodstream infection caused by pseudomonas aeruginosa in rabbits. American Journal of Respiratory and Critical Care Medicine. 2017, 195, A2646-A2646. http://dx.doi.org/10.1164/ajrccm-conference.2017.195.1 MeetingAbstracts.A2643

DUVAL, R.E., GRARE, M. and DEMORÉ, B. Fight against antimicrobial resistance: we always need new antibacterials but for right bacteria. Molecules. 2019, 24(17), 3152-3160. http://dx.doi.org/10.3390/molecules24173152

ESPINEL-INGROFF, A., et al. Quality Control and Reference Guidelines for CLSI Broth Microdilution Susceptibility Method (M38-A Document) for Amphotericin B, Itraconazole, Posaconazole, and Voriconazole. Journal of Clinical Microbiology. 2005, 43(10), 5243-5246.

http://dx.doi.org/10.1128/JCM.43.10.5243-5246

FAIZI, M., et al. Design, Synthesis and Pharmacological Evaluation of Novel 2-[2-(2-Chlorophenoxy) phenyl]-1,3,4-oxadiazole Derivatives as Benzodiazepine Receptor Agonists. Iranian Journal of Pharmaceutical Research. 2012, 11(1), 83-90.

GOLAN, D.E., TASHIIAN JUNIOR, A.H., ARMSTRONG, E.J. and ARMSTRONG, A.W. Princípios de farmacologia: a base fisiopatológica da farmacoterapia. 3rd ed. Rio de Janeiro: Guanabara Koogan, 2014.

GUIMARÃES, D.O., MOMESSO, L.S. and PUPO, M.T. Antibióticos: importância terapêutica e perspectivas para a descoberta e desenvolvimento de novos agentes. Química Nova. 2010, 33(3), 667-679. http://dx.doi.org/10.1590/\$0100-40422010000300035

IRFAN, M., ALAM, S., MANZOOR, N. and ABID, M. Effect of quinoline based 1,2,3-Triazole and its structural analogues on growth and virulence attributes of Candida albicans. PLoS One. 2017, 12(4), 1-23. http://dx.doi.org/10.1371/journal.pone.0175710

KNOP, L. B. and MARIA, D.A. Métodos substitutivos e a experimentação animal: um enfoque inovador. Revista da Sociedade Brasileira de Ciência em Animais de Laboratório. 2017, 4(2), 101-114.

LEE, H. and LEE, D.G. Novel Approach into Efficient Antifungal Drug Action. Journal of microbiology and biotechnology. 2018, 28(11), 17711781. http://dx.doi.org/10.4014/jmb.1807.07002 
LI, Y., et al. Synthesis, insecticidal activity, and structure-activity relationship (SAR) of anthranilic diamides analogs containing oxadiazole rings. Organic and Biomolecular Chemistry. 2013, 11(24), 3979-3988. http://dx.doi.org/10.1039/c3ob40345a.ISSN 1477-0539

LIPINSKI, C.A. Lead and drug-like compounds: the rule-of-five revolution. Drug discovery today: Technologies. 2004, 1(1), $337-341$. http://dx.doi.org/10.1016/j.ddtec.2004.11.007

LIPINSKI, C.A., LOMBARDO, F., DOMINY, B.W. and FEENEY, P.J. Experimental and computational approaches to estimate solubility and permeability in drug discovery and development settings. Advanced Drug Delivery Reviews. 1997, 23(1-3), 4-25. http://dx.doi.org/10.1016/S0169-409X(96)00423-1

MODA, T.L. Modelagem in silico de propriedades farmacocinéticas para a avaliação de candidatos a novos fármacos. 2011. São Carlos: Universidade de São Paulo, 2011.Tese de doutorado.

MORALES, G., PAREDES, A., SIERRA, P. and LOYOLA, L.A. Antimicrobial activity of three baccharis species used in the traditional medicine of northern Chile. Molecules. 2008, 13(4), 790-794. http://dx.doi.org/10.3390/molecules13040790

MURRAY, P., ROSENTHAL, K.S. and PFALLER, M.A. Microbiologia Médica. 7th ed. Rio de Janeiro: Elsevier Brasil, 2015.

NEVES, P.R., MAMIZUKA, E.M., LEVI, C.E. and LICOPAN, N. Pseudomonas aeroginosas multirresistente: um problema endêmico no Brasil. Jornal Brasileiro de Patologia e Medicina Laboratorial. 2011, 47(4), 409-420. http://dx.doi.org/10.1590/S1676-24442011000400004

OLIVEIRA, M.L.G. Avaliação in silico do potencial farmacológico e toxicológico de friedelanos, lupanos e derivados. Belo Horizonte: Universidade Federal de Minas Gerais, 2014. Tese de doutorado.

PANKRATEVA, V.E., et al. One-Pot Synthesis of 3,5-Disubstituted 1,2,4-Oxadiazoles Using Catalytic System NaOH-DMSO. Russian Journal of Organic Chemistry. 2018, 54(8), 1250-1255. http://dx.doi.org/10.1134/S1070428018080213

PAPA, E., ARNOD, J.A., SANGION, A. and GRAMATICA, P., 2017. In Silico Approaches for the Prediction of In Vivo Biotransformation Rates. In: ROY, K. Advances in QSAR Modeling. New York: Springer, pp. 425-451.

PERRIN, D.D. and AMAREGO, W.L.F. Purification of Laboratory Chemicals. Oxford: Pergamon Press, 1996.

PRESTINACI, F., PEZZOTTI, P. and PANTOSTI, P. Antimicrobial resistance: a global multifaceted phenomenon. Pathogens and Global Health. 2015, 109(7), 309-318. http://dx.doi.org/10.1179/2047773215Y.0000000030

RANG, H.P., RITTER, J.M., FLOWER, R.J. and HENDERSON, G. Farmacologia. 8th ed. Rio de Janeiro: Elsevier, 2016.

ROCHA, D.S., et al. Potential Antimicrobial and Chemical Composition of Essential Oils from Piper caldense Tissues. Journal of the Mexican Chemical Society. 2016, 60(3), 148-151. http://dx.doi.org/10.29356/jmcs.v60i3.97.

ROSSITER, S.E., FLETCHER, M.H. and WUEST, W.M. Natural Products as Platforms to Overcome Antibiotic Resistance. Chemical Reviews. 2017, 117(19), 12415-12474. http://dx.doi.org/10.1021/acs.chemrev.7b00283

RYU, H-C., HONG, Y-T. and KANG, S-K. Palladium-catalyzed Carbonylative Coupling of Hypervalent lodonium Salts with Amidoximes: Synthesis of Oxadiazoles. Heterocycles. 2001, 52(2), 985-988. http://dx.doi.org/10.3987/COM-00-S(I)16

SANGSHETTI, J.N., NAGAWADE, R.R. and SHINDE, D.B. Synthesis of novel 3-(1-(1-substituted piperidin-4-yl)-1H-1,2,3-triazol-4-yl)-1,2,4oxadiazol-5(4H)-one as antifungal agents. Bioorganic \& Medicinal Chemistry Letters. 2009, 19(13), 3564-3567.

http://dx.doi.org/10.1016/j.bmcl.2009.04.134\&nbsp

SANTOS, C.E.M. Toxicologia in silico: uma nova abordagem para análise do risco químico. Revista Intertox de Toxicologia, Risco Ambiental e Sociedade. 2011, 4(1), 47-63. http://dx.doi.org/10.22280/revintervol4ed1.66

SANTOS, C.E.M. and RODRIGUES, A.S. Toxicologia in silico: contexto de aplicação e o modelo de custo-efetividade nos testes alternativos. RevInter Revista Intertox de Toxicologia, Risco Ambiental e Sociedade. 2011, 4(3), 92-113. http://dx.doi.org/10.22280/revintervol4ed3.97

SARVI, I., GHOLIZADEH, M. and IZADYAR, M. Threonine stabilizer-controlled well-dispersed small palladium nanoparticles on modified magnetic nanocatalyst for Heck cross-coupling process in water. Applied Organometallic Chemistry. 2018, 33(3), 1-10.

http://dx.doi.org/10.1002/aoc.4645

SAUER, A.C., et al. A Straightforward and High-Yielding Synthesis of 1,2,4-Oxadiazoles from Chiral N-Protected $\alpha$-Amino Acids and Amidoximes in Acetone-Water: An Eco-Friendly Approach. Journal of Chemistry. 2019, 2019, 1-9. http://dx.doi.org/10.1155/2019/8589325

SIDRIM, J.J.C. and ROCHA, M.F.G. Micologia Médica à luz de autores contemporâneos. 2nd ed. Rio de Janeiro: Guanabara Koogan, 2010.

SILVA, A.S., SILVA, J.M., ALMEIDA, A.V. and RAMOS, C.S. Herbivory Causes Chemical and Biological Changes on Essential Oil from Piper marginatum Leaves. The Natural Products Journal. 2016, 6(4), 313-317. http://dx.doi.org/10.2174/2210315506666160916152524

SILVA, D.F. Avaliação da atividade biológica do b-citroneol sobre Candida albicans. João pessoa: Universidade Federal da Paraíba, 2016. Dissertação de mestrado.

SINGH, P., et al. Synthesis and evaluation of substituted diphenyl-1,3,4-oxadiazole derivatives for central nervous system depressant activity. Bioorganic \& Medicinal Chemistry Letters. 2012, 2(1), 1-8. http://dx.doi.org/10.1186/2191-2858-2-8

SRINIVAS, N., SANDEEP, K.S., ANUSHA, Y. and DEVENDRA, B.N. In vitro cytotoxic evaluation and detoxification of monocrotaline (Mct) alkaloid: an in-silico approach. International Invention Journal Biochemistry Bioinformatics. 2014. 2(2), 20-29. 
TALE, R.H., et al. Synthesis and anti-bacterial, anti-fungal activity of novel 1,2,4-oxadiazole. Journal of Chemical and Pharmaceutical Research. 2011, 3(2), 496-505. http://dx.doi.org/10.4103/2231-4040.161515

TERRÍVEL, J., et al. Conhecimento dos médicos relativo à prescrição de antibióticos e à resistência microbiana: estudo piloto de comparação de questionário online vs papel. Revista de Epidemiologia e Controle de Infecção. 2013, 3(3), 93-98. http://dx.doi.org/10.17058/reci.v3i3.3956

VARANO, N., et al. Infecções por Candida spp em pacientes imunodeprimidos. Journal of Infection Control. 2019, 8(1), 17-23.

WALSH, C. Antibiotics: actions, origins, resistance. Protein Science. 2004, 13(11), 3059-3060. http://dx.doi.org/10.1110/ps.041032204

ZAKERI, M., HERAVI, M.M. and ABOUZARI-LOTF, E. A new one-pot synthesis of 1,2,4-oxadiazoles from aryl nitriles, hydroxylamine and crotonoyl chloride. Journal of Chemical Sciences. 2013, 125(4), 731-735. http://dx.doi.org/10.1007/s12039-013-0426-6

ZORZI, R.R. Planejamento, síntese e avaliação da atividade antimicrobiana de furfurilidênicos frente a micro-organismos causadores de infecções hospitalares. São Paulo: Universidade de São Paulo, 2013. Dissertação de mestrado.

Received: 1 May 2020 | Accepted: 7 July 2020 | Published: 16 February 2022

This is an Open Access article distributed under the terms of the Creative Commons Attribution License, which permits unrestricted use, distribution, and reproduction in any medium, provided the original work is properly cited. 